\title{
Van Drimmelen, Rob 1998. Faith in a global economy: A primer for Christians.
}

\section{Geneva: WCC Publications. 170 Pages. Price: US\$9.95}

\section{Reviewer: Rev G J Volschenk}

What is the relationship between faith and economics? What is the balance between faith and material things? Who is responsible for the poor people in the world today? These are the questions which van Drimmelen tries to answer in his book. He rightfully says that the Bible and economics stand in a very complex relationship and there are no simple answers to these questions. In the preface, Niles (1998:ix) gives us an exact description of the goal of Van Drimmelen's book:

With clarity, he unravels for readers the complex economic relations that exist today, lays bare the messianic claims of the world market and debunks the religious language of economic pretensions. With equal skill he shows the connections between economics, politics and the Christian faith, the ways in which oconomic considerations are becoming determinative for political thinking and how these impact on ethics.

But when I read the book, I was very disappointed not to find any model according to which one could describe the "complex of economic relations that exist today" and no model that could show the modern reader the complex connections or relationship between politics, economics and religion. Van Drimmelen is correct to admit that it is a complex relationship, but he fails in clarifying the relationship for his readers.

The questions that I asked myself are the following: Is he differentiating clearly enough between the ancient economic system and the industrial, postmodern economic system? Is he guilty of the fallacies of anachronism and ethnocentrism? The use of models should have helped him to clarify complex relations and would have helped the reader to understand such relationships. Models would enable him to compare the ancient economic system of the Bible and the economic system of the industrial age. If he had used social-scientific models, described the complex relationships and showed how politics, economics and religion fit in the model, only then would he have been able to set out a principle-based philosophy for the responsibilities and ethics of postmodern economics and of helping the poor.

Another criticism pertains to Van Drimmelen's perspective on political and economic institutions. He says that these are "just mechanisms and institutions". Do you get "just" institutions or just people? Justice and righteousness are characteristics of principle-oriented people. Some people who operate in a political or economic system do have principle-oriented characteristics.

Furthermore, there is no such thing as a presuppositionless or purely objective point of view. Van Drimmelen is writing from an ecumenical perspective or paradigm, with all its strengths and shortcomings in relation to other theological paradigms. He rightfully asks the question: "How can we live out our Christian faith in a global economy?" This is not only an ecumenical question, but also an existential one, asked by all Christians.

Van Drimmelen (1998:93-113) rightfully focusess our attention on the importance of land as the third production factor in modern economics. But again, because of the lack of a social-scientific model on the land and jubilee in the Bible, he makes far-fetched statements without a sound basis and a way of testing his results. For example: "At the same time there is a warning against those who think they own the land, especially against those who live in the city - which in the Hebrew Scriptures symbolises power, oppression and monopoly" (Van Drimmelen 1998:93). 
He closes his book on a positive note, namely "Signs of Hope." He mentions the hope given to people by the micro-credit campaigns to belp them to start their own businesses. This is a step forward. but we must be aware of the dangers of debt in all its forms, not just debts of governments and institutions. Micro or cash loans are just another form of enslavement and not empowerment, its original intention.

Van Drimmelen could have made a lot more of these data, explaining them to his readers with the help of models, instead of merely describing them. It remains, however, a readable book for the interested reader. 